\title{
Chronic effects of welding exposure on pulmonary function tests and respiratory symptoms
}

\author{
Özlem Özdemir, Numan Numanoğlu, Uğur Gönüllü, İsmail Savaş, Doğanay Alper, \\ Hilmi Gürses
}

\begin{abstract}
Objectives-The respiratory effects of exposure to welding fumes have been investigated in numerous studies; but results of these studies have not been consistent. The aim of the present study was to investigate the respiratory effects of welding exposure in a large group of manual arc welders exposed primarily to mild steel welding processes in confined spaces without respiratory protection.
\end{abstract}

Methods-Respiratory symptoms and spirometry were studied in 110 welders and 55 controls. The welders and controls were of similar average age and height; smoking habits of the groups were similar. Chest $x$ ray films were taken to exclude people with radiological abnormalities that may influence pulmonary function tests. Welders were grouped according to smoking habits and duration of employment ( $<20$ years or $>20$ years).

Results-No gross radiological abnormalities were found. Respiratory symptoms and chronic bronchitis were more prevalent in welders $(P<0.05)$. Welders who were smokers showed a higher frequency of chronic bronchitis than controls who smoked ( $P<0.05)$. No significant difference in the occurrence of chronic bronchitis was found between welders who smoked and welders who were non-smokers or exsmokers. Compared with the controls, forced vital capacity (FVC), forced expiratory volume in one second $\left(F_{1}\right)$, peak expiratory flow (PEF), and maximum midexpiratory flow (MMEF) were significantly lower in welders (mean values of FVC for welders and controls were 86.06 (25.74) and 96.40 (13.03); and values for $\mathrm{FEV}_{1}$ were $87.54(13.70)$ and $95.36(12 \cdot 40)$ respectively; $P<0.01)$. There was no significant difference in pulmonary function tests between welders who were non-smokers and controls who were non-smokers; whereas FVC, FEV PEF, and MMEF were significantly lower in welders who smoked than controls who smoked $(P<0.01)$. There were no significant differences in pulmonary function tests and occurrence of chronic bronchitis between welders with more or less than 20 years at work.

Conclusion-Welders working in conditions of inadequate ventilation, have increased risk of chronic bronchitis and impairment of pulmonary function.

(Occup Environ Med 1995;52:800-803)
Keywords: welding; occupational lung diseases; spirometry

Welding refers to any process of joining pieces of metal at joint faces that have been made soft or liquid by heat or pressure. About 800000 workers are employed full time as welders worldwide; larger numbers are estimated to perform welding intermittently as part of their work duties.

One of the most common processes, electric arc welding, is performed with hand held electrodes coated with suitable slag forming flux to protect the arc. The high temperature of the process heats both the base metal pieces to be joined and the filler metal from a consumable electrode or wire, which is fed into the weld. Molten fluxes from the consumable electrodes carry away impurities in a liquid form; and when heated consumable electrodes generate a shielding gas to protect the weld from oxidation. Fluxes are commonly a major source of inhalation exposures. ${ }^{12}$ The material most commonly welded is mild steel; but stainless steel and aluminium welding are also widely practised. ${ }^{2}$

The adverse health effects of welding come from chemical, physical, and radiation hazards. Common chemical hazards include particulates (lead, nickel, zinc, iron oxide, copper, cadmium, fluorides, manganese, chromium) and gases (carbon monoxide, oxides of nitrogen, ozone). Each welding technique and application produce a characteristic range of particulate composition and morphology. ${ }^{12}$

Several epidemiological studies in welders have been carried out in which the prevalence of respiratory symptoms and pulmonary impairment has been measured. The severity and prevalence of respiratory effects among welders vary in different studies. ${ }^{23}$ Some have concluded that welders do not have an increased risk of developing respiratory symptoms, whereas others have concluded that they have. ${ }^{4-9}$

The main object of our study was to detect the chronic effects of welding exposure on pulmonary symptoms and pulmonary function tests.

\section{Subjects and methods}

Welders comprised all the welders in the workshops of two companies in the municipality of Ankara. Selection was regardles of special types of working procedure or types of electrodes. Welders exposed to any other chemicals known to be injurious to the lung were excluded. 
Clerks from the same companies were selected as controls. These were 55 men of similar age distribution and socioeconomic situation, but who had no occupational dust or gas exposure.

Informed consent was obtained after the nature of all the procedures was fully explained to each welder and control.

Each person underwent a detailed medical, social, and occupational history; physical examination; chest radiograph; and spirometry. A modification of the British MRC questionnaire on respiratory symptoms was used. ${ }^{10}$ Cough, sputum, dyspnoea, wheeze, fever, chest pain, and other complaints were asked about and "cough and phlegm on most days for as much as three months of the year, for at least two consecutive years" was used as the definition of chronic bonchitis. The questionnaires were administered by one of the authors (ÖÖ).

All investigations (administering the questionnaire, physical examination, chest $x$ ray film, spirometry) were performed between 830 and 1030 am before the subjects started that day's work.

Welders were grouped according to smoking habits as smoker (currently smoked), exsmoker (stopped smoking for at least three months), and non-smoker (never smoked).

Welders were divided into two groups depending upon duration of employment, group 1 had worked $<20$ years and group 2 $>20$ years.

A chest $x$ ray film was obtained on the same equipment for each person. Chest $x$ ray films were mixed and read blindly by two chest physicians to exclude people from the study with radiological abnormalities that may have influenced pulmonary function tests.

Spirometric tests were performed and the following variables were examined: forced vital

Table 1 Mean age, height, and smoking habits of the study population

\begin{tabular}{lccc}
\hline & Welders & Controls & P values \\
\hline Mean (SD) age: & $35 \cdot 3(6 \cdot 4)$ & $36 \cdot 3(10 \cdot 0)$ & $0 \cdot 44$ \\
Range & $22-54$ & $17-55$ & \\
Mean (SD) height (cm): & $169 \cdot 10(5 \cdot 23)$ & $170 \cdot 30(5 \cdot 40)$ & $0 \cdot 17$ \\
Range & $153-182$ & $155-182$ & \\
Smokers (n(\%)) & $74(67 \cdot 3)$ & $40(72 \cdot 7)$ & \\
Non-smokers (n(\%)) & $23(20 \cdot 9)$ & $11(20)$ & \\
Exsmokers (n(\%)) & $13(11 \cdot 8)$ & $4(7 \cdot 3)$ & \\
\hline
\end{tabular}

$\mathrm{P}=0.64$ for smoking habits of welders $v$ controls; df 2 .

Table 2 Smoking history of study groups (n(\%))

\begin{tabular}{lllll}
\hline & Smokers & Non-smokers & Exsmokers & Total \\
\hline Group 1 & $42(62 \cdot 7)$ & $16(23 \cdot 9)$ & $9(13 \cdot 4)$ & $67(100)$ \\
Group 2 & $32(74 \cdot 4)$ & $7(16 \cdot 3)$ & $4(9 \cdot 3)$ & $43(100)$ \\
Controls & $40(72 \cdot 4)$ & $11(20)$ & $4(7 \cdot 3)$ & $55(100)$ \\
\hline
\end{tabular}

Table 3 Respiratory symptoms of study population (n(\%))

\begin{tabular}{lccl}
\hline Symptom & Group 1 $(n=67)$ & Group 2 $(n=43)$ & Controls $(n=55)$ \\
\hline Cough & $33(49 \cdot 2)$ & $18(41 \cdot 8)$ & $8(14 \cdot 5)$ \\
Sputum & $31(46 \cdot 2)$ & $17(39 \cdot 3)$ & $8(14 \cdot 5)$ \\
Dyspnoea & $10(14 \cdot 9)$ & $8(18 \cdot 6)$ & $1(1 \cdot 8)$ \\
Wheeze & $5(7 \cdot 4)$ & $3(6 \cdot 9)$ & 0 \\
Fever & $1(1 \cdot 5)$ & $2(4 \cdot 6)$ & 0 \\
Chest pain & $6(8 \cdot 9)$ & $3(6 \cdot 9)$ & 0 \\
Other & $6(8 \cdot 9)$ & 0 & 0 \\
\hline
\end{tabular}

capacity (FVC); forced expiratory volume in one second $\left(\mathrm{FEV}_{1}\right) ; \mathrm{FEV}_{1} / \mathrm{FVC}$; peak expiratory flow (PEF); maximum midexpiratory flow (MMEF); maximum expiratory flow when $75 \%$ of vital capacity remained to be expired $\left(\mathrm{MEF}_{75}\right)$; maximum expiratory flow when $50 \%$ of the vital capacity remained to be expired $\left(\mathrm{MEF}_{50}\right)$; maximum expiratory flow when $25 \%$ of the vital capacity remained to be expired $\left(\mathrm{MEF}_{25}\right)$. The spirometric tests (made when the subjects were seated and wearing a nose clip) were made with a Gould pulmonary analysis computer system, which was a dry spirometer. The spirometer system was designed to meet the performance recommendations of the American Thoracic Society. ${ }^{11}$ A forced expired vital capacity manoeuvre was recorded. Everyone, both exposed and unexposed, was studied by the same technician and with the same equipment. All measurements were registered at least three times for each person, and the best results were selected. All volumes were corrected to body temperature and pressure saturated with water vapour (BTPS). Spirometric results were expressed both as a percentage of the predicted value for a normal person of corresponding age and height and as absolute mean values for main groups; but for subgroups only the percentage of predicted values were used.

Statistical analysis was by $t$ test, analysis of variance, and $\chi^{2}$ test. $P$ values of $<0.05$ in two tailed tests were considered to be significant.

\section{Results}

All of 110 welders had been doing electric arc welding and sometimes oxyacetylene welding. All welders had been working for about 25 hours a week in confined spaces with poor ventilation and without respiratory protective devices.

Mean (range) duration of employment of welders was 16.10 (1-30) years. Group 1 (worked $<20$ years) was composed of 67 welders; the remaining 43 welders comprised group 2 (worked $>20$ years).

There were no significant differences between the mean age, height, and smoking habits of welders and controls (table 1). Mean age of smoker controls was $36.3(8.9)$ and the mean age of smoker welders was $34.9(6.0)$; the difference was not significant $(P=0.32)$. Mean age of non-smoking groups was 30.9 $(10 \cdot 8)$ for controls and $34.3(7 \cdot 5)$ for welders; the difference was not significant $(P=0.31)$. Because of the selection criteria, the men in group 2 were on average rather older than the group 1 men (39.3 (4.5) v $32 \cdot 7(6 \cdot 2))$.

Smoking habits of welders in group 1 , welders in group 2 , and controls were similar $(P=0.63$; degrees of freedom (df) 4, table 2). Cumulative pack-years of smoking were greater for control subjects who smoked $(17 \cdot 27(12 \cdot 60))$ than for welders who smoked $(14.28(7 \cdot 80))$; but the difference was not significant $(P=0 \cdot 124$; df 112$)$.

No gross radiological abnormalities were detected; no worker was excluded because of such abnormalities. Tables 3 and 4 show the 
Table 4 Distribution of respiratory symptoms in welders by smoking habits (n(\%))

\begin{tabular}{llll}
\hline Symptoms & Smokers $(n=74)$ & Non-smokers $(n=23)$ & Exsmokers $(n=13)$ \\
\hline Cough & $39(52 \cdot 7)$ & $8(34 \cdot 8)$ & $4(30 \cdot 7)$ \\
Sputum & $35(47 \cdot 3)$ & $8(34 \cdot 8)$ & $5(38 \cdot 4)$ \\
Dyspnoea & $15(20 \cdot 3)$ & $1(4 \cdot 3)$ & $2(15 \cdot 4)$ \\
Wheeze & $4(5 \cdot 4)$ & $3(13)$ & $1(7 \cdot 7)$ \\
Fever & $2(2 \cdot 7)$ & 0 & $1(7 \cdot 7)$ \\
Chest pain & $6(8 \cdot 1)$ & $2(8 \cdot 7)$ & $1(7 \cdot 7)$ \\
Other & $4(5 \cdot 4)$ & 0 & $2(15 \cdot 4)$ \\
\hline
\end{tabular}

Table 5 Distribution of subjects with chronic bronchitis $(n(\%))$

\begin{tabular}{lll}
\hline & \multicolumn{2}{l}{ Chronic bronchitis } \\
\cline { 2 - 3 } & Present & Absent \\
\hline Welders $(\mathrm{n}=110)$ & $33(30)$ & $77(70)$ \\
Controls $(\mathrm{n}=55)$ & $6(10 \cdot 9)$ & $49(89 \cdot 1)$ \\
Total $(\mathrm{n}=165)$ & 39 & 126 \\
\hline
\end{tabular}

Table 6 Distribution of smokers with chronic bronchitis $(n(\%))$

\begin{tabular}{llll}
\hline & \multicolumn{3}{l}{ Chronic bronchitis } \\
\cline { 2 - 4 } & Present & Absent & Total \\
\hline Welders & $26(35 \cdot 1)$ & $48(64 \cdot 9)$ & $74(100)$ \\
Controls & $5(12 \cdot 5)$ & $35(87 \cdot 5)$ & $40(100)$ \\
\hline
\end{tabular}

Table 7 Prelalence of chronic bronchitis according to duration of welding $(n(\%))$

\begin{tabular}{lll}
\hline & \multicolumn{2}{l}{ Chronic bronchitis } \\
\cline { 2 - 3 } & Present & Absent \\
\hline Group 1 $(\mathrm{n}=67)$ & $20(29 \cdot 9)$ & $47(70 \cdot 1)$ \\
Group 2 $(\mathrm{n}=43)$ & $13(30 \cdot 2)$ & $30(69 \cdot 8)$ \\
\hline
\end{tabular}

Table 8 Mean (SD) spirometric variables of welders and controls

\begin{tabular}{lrrr}
\hline & \multicolumn{1}{l}{$\begin{array}{l}\text { Welders } \\
(n=110)\end{array}$} & \multicolumn{1}{c}{$\begin{array}{l}\text { Controls } \\
(n=55)\end{array}$} & P values \\
\hline FVC & $3.86(0.76)$ & $4.38(0.80)$ & 0.0001 \\
FEV $_{1}$ & $3.29(0.59)$ & $3.57(0.60)$ & 0.0048 \\
FEV $_{1} /$ FVC & $85.93(8.67)$ & $82.25(9.76)$ & 0.0148 \\
$\mathrm{PEF}_{\text {MMEF }}$ & $6.86(1.68)$ & $7.79(1.49)$ & 0.0007 \\
$\mathrm{MEF}_{75}$ & $3.42(1.14)$ & $3.92(1.05)$ & 0.0064 \\
$\mathrm{MEF}_{50}$ & $6.46(1.71)$ & $6.66(1.67)$ & 0.5397 \\
$\mathrm{MEF}_{25}$ & $4.33(1.37)$ & $4.59(1.39)$ & 0.3248 \\
& $1.86(0.88)$ & $2.01(0.84)$ & 0.3693 \\
\hline
\end{tabular}

Table 9 Pulmonary function test results (mean (SD) \% predicted)

\begin{tabular}{|c|c|c|c|}
\hline & $\begin{array}{l}\text { Welders } \\
(n=110)\end{array}$ & $\begin{array}{l}\text { Controls } \\
(n=55)\end{array}$ & $P$ values \\
\hline $\begin{array}{l}\text { FVC } \\
\text { FEV }_{1} \\
\text { FEV }_{1} / \mathrm{FVC} \\
\mathrm{PEF} \\
\mathrm{MMEF} \\
\mathrm{MEF}_{75} \\
\mathrm{MEF}_{50} \\
\mathrm{MEF}_{25}\end{array}$ & $\begin{array}{c}86.06(25.74) \\
87.54(13.7) \\
106.20(10.40) \\
76.03(18 \cdot 2) \\
76.09(23.5) \\
83.46(21.60) \\
87.07(25.08) \\
84.74(36.58)\end{array}$ & $\begin{array}{r}96.4(13.03) \\
95.36(12.40) \\
103.09(11.80) \\
88.47(16.45) \\
93.03(25 \cdot 10) \\
88.17(20 \cdot 20) \\
93.35(25.90) \\
92.23(38.88)\end{array}$ & $\begin{array}{l}0.0000 \\
0.0005 \\
0.0802 \\
0.0000 \\
0.0001 \\
0.2490 \\
0.1965 \\
0.2941\end{array}$ \\
\hline
\end{tabular}

Table 10 Pulmonary function test results of welders and controls who had never smoked (mean (SD) \% predicted)

\begin{tabular}{|c|c|c|c|}
\hline & $\begin{array}{l}\text { Welders } \\
(n=23)\end{array}$ & $\begin{array}{l}\text { Controls } \\
(n=11)\end{array}$ & $P$ values \\
\hline $\begin{array}{l}\text { FVC } \\
\text { FEV } \\
\text { FEV }_{1} / \text { FVC } \\
\text { PEF } \\
\text { MMEF }\end{array}$ & $\begin{array}{r}81 \cdot 10(13.30) \\
85.80(14.00) \\
109.70(8.90) \\
73.65(14.45) \\
81.96(19.40)\end{array}$ & $\begin{array}{c}90 \cdot 00(14 \cdot 20) \\
91 \cdot 10(6.90) \\
108 \cdot 80(8.50) \\
74.63(18.05) \\
85.45(17.60)\end{array}$ & $\begin{array}{l}0.0939 \\
0 \cdot 2615 \\
0 \cdot 7884 \\
0 \cdot 8699 \\
0.6023\end{array}$ \\
\hline
\end{tabular}

Table 11 Pulmonary function test results of welders and controls who were smokers (mean (SD) \% predicted)

\begin{tabular}{|c|c|c|c|}
\hline & $\begin{array}{l}\text { Welders } \\
(n=74)\end{array}$ & $\begin{array}{l}\text { Controls } \\
(n=40)\end{array}$ & $P$ values \\
\hline FVC & $87.00(16.70)$ & $97.65(12.50)$ & 0.0006 \\
\hline $\mathrm{FEV}_{1}$ & $87 \cdot 50(13.60)$ & $96.30(13 \cdot 70)$ & 0.0013 \\
\hline $\mathrm{FEV}_{1} / \mathrm{FVC}$ & $105 \cdot 20(11.00)$ & $101.8(11 \cdot 30)$ & $0 \cdot 1250$ \\
\hline PEF & $75 \cdot 50(17 \cdot 70)$ & $90 \cdot 70(13.30)$ & 0.0000 \\
\hline MMEF & $73.60(24.50)$ & $94.80(26 \cdot 50)$ & 0.0000 \\
\hline
\end{tabular}

distributions of respiratory symptoms. Chronic bronchitis was found in $30 \%$ of welders, and $10.9 \%$ of controls $(P=0.0113$; df 1 , table 5). Chronic bronchitis was found in $21.7 \%$ of welders who were non-smokers, $15.4 \%$ of welders who were exsmokers, but none of controls who were non-smokers had chronic bronchitis. The frequency of chronic bronchitis in welders who smoked was higher than the controls who smoked $(P=0.017$; df 1 , table 6). The frequency of chronic bronchitis was similar in welders who smoked and welders who were non-smokers or exsmokers $(P=0 \cdot 14 ; \mathrm{df} 1)$. Prevalence of chronic bronchitis was not statistically different in groups 1 and $2(P=0.96$, df 1 , table 7$)$.

Tables 8 and 9 show spirometric variables of welders and controls. The FVC, FEV $P E F$, and MMEF were significantly decreased in welders. There were no significant differences between spirometric variables of welders who had never smoked and controls (table 10). The FVC, $\mathrm{FEV}_{1}, \mathrm{PEF}$, and MMEF of welders who smoked showed significant differences from those of controls who smoked (table 11). The pulmonary function test results of group 1 and group 2 were not different; but in the control group FVC, $\mathrm{FEV}_{1}$, PEF, and MMEF were significantly higher than in groups 1 and 2 (table 12).

\section{Discussion and conclusion}

The biological effects of exposure to welding fumes have generated much interest and numerous studies have been carried out in welders. The results of former epidemiological studies have not been consistent. ${ }^{4-912-18}$ These surveys are difficult to compare because of differences in study populations, industrial settings, welding techniques and duration of exposures. In our study, all of the 110 welders were electric arc welders that used mostly mild steel and sometimes aluminium as the base metal. The welders performed welding operations manually in poorly ventilated confined spaces without respiratory protective devices and local exhaust ventilation. For manual metal arc or mild steel welding the primary constituents of the fume are $\mathrm{Fe}, \mathrm{Mn}, \mathrm{Si}, \mathrm{Na}$, $\mathrm{Ca}$, and $\mathrm{F}$. Welding produces several gaseous pollutants through thermal decomposition of the electrode coating. Some aluminum welding processes produce high ozone concentrations. ${ }^{12}$

Respiratory symptoms and chronic bronchitis were more prevalent in welders. Welders who smoked showed a higher frequency of chronic bronchitis than controls who smoked. 
Table 12 Pulmonary function test results of groups 1 and 2 (mean (SD) \% predicted)

\begin{tabular}{|c|c|c|c|c|c|c|}
\hline & $\begin{array}{l}\text { Group 1 } \\
(n=67)\end{array}$ & $\begin{array}{l}\text { Group 2 } \\
(n=43)\end{array}$ & Controls & $\begin{array}{l}P \text { values } \\
\text { groups } \\
1 v 2\end{array}$ & $\begin{array}{l}P \text { values } \\
\text { group } \\
1 \text { v controls }\end{array}$ & $\begin{array}{l}P \text { values } \\
\text { group } \\
2 \text { v controls }\end{array}$ \\
\hline $\begin{array}{l}\text { FVC } \\
\text { FEV }_{1} \\
\text { FEV }_{1 / F V C} \\
\text { PEF } \\
\text { MMEF }\end{array}$ & $\begin{array}{r}85 \cdot 60(14 \cdot 30) \\
87 \cdot 20(11 \cdot 50) \\
106 \cdot 30(10 \cdot 9) \\
75 \cdot 77(18 \cdot 00) \\
77 \cdot 68(21 \cdot 50)\end{array}$ & $\begin{array}{c}86 \cdot 70(17 \cdot 90) \\
88.04(16 \cdot 70) \\
106 \cdot 04(9 \cdot 60) \\
76 \cdot 42(18 \cdot 20) \\
73.60(26 \cdot 50)\end{array}$ & $\begin{array}{r}96.40(13.03) \\
95.36(12.04) \\
103.09(11.80) \\
88.47(16.45) \\
93.03(25 \cdot 10)\end{array}$ & $\begin{array}{l}0.724 \\
0.757 \\
0 \cdot 899 \\
0 \cdot 850 \\
0.382\end{array}$ & $\begin{array}{l}0.0000 \\
0.0003 \\
0 \cdot 1250 \\
0.0001 \\
0.0004\end{array}$ & $\begin{array}{l}0.0025 \\
0.0145 \\
0.1920 \\
0.0009 \\
0.0003\end{array}$ \\
\hline
\end{tabular}

No significant difference in the occurrence of chronic bronchitis was found between welders who smoked and welders who were non-smokers or exsmokers. The bronchitis that develops in welders is a non-specific response to irritant fumes originating from the welding process. It is generally accepted that simple chronic bronchitis may be caused by occupational exposures. ${ }^{19} \mathrm{We}$ think that the welding process may produce irritant fumes enough to cause "industrial bronchitis".

In welders FVC, $\mathrm{FEV}_{1}, \mathrm{PEF}$, and $\mathrm{MMEF}$ were significantly lower than in controls. Some previous studies showed no effect of welding exposure on pulmonary function tests. ${ }^{5616-18}$ Hayden et al showed that welders working in the engineering industry seemed to have no increased risk of chronic obstructive lung disease; and they emphasised that the factories in which their subjects had worked had been spacious and well ventilated. ${ }^{18}$ Our welders worked in confined spaces with poor ventilation and without respiratory protective devices. We think that working conditions are important for welders' respiratory health.

There were no differences between the pulmonary function test results of welders and controls who were non-smokers. Welders who smoked had lower FVC, FEV $_{1}$, PEF, MMEF values than controls who smoked.

In cases of chronic exposures it has often been difficult to differentiate between the effects due to occupation and those due to cigarette smoking. Cigarette smoking may potentiate the effects of dust inhalation by interfering with bronchial clearance mechanisms. It has been further suggested that occupational exposure and cigarette smoking influence lung function in an additive manner. ${ }^{20}$ Our results showed that only the differences between welders and controls who smoked were significant. These findings support the results of some of the other studies..$^{914}$

As significant differences were found in spirometry before the workshift, the lung function effects measured are attributed either to an irreversible chronic effect or possibly to a persistent effect from welding the day before. We think that it is necessary to measure lung functions after a long period without welding exposure (for example, after the annual leave).

The frequency of chronic bronchitis and spirometric variables were not different in welders who worked more than 20 years and welders who worked less than 20 years. But mean duration of employement of welders in group 1 was $11.95(5.60)$ years (also a very long exposure). Some studies showed a doseresponse relation, ${ }^{49}$ but McMillan and Heath failed to show any relation between duration of exposure and respiratory disturbance. ${ }^{17}$

Our study design was cross sectional and all participants were at work. A problem with cross sectional studies is that only healthy workers who were physically fit tended to remain at work to be surveyed; workers ill due to occupational exposure may have already left the workforce. ${ }^{21}$ Chronic bronchitis and impairment of pulmonary function may reduce the working capacity, and welders whose working capacity has been reduced might have already left the workforce. Therefore it can be assumed that there is a healthy worker effect. So we think that the differences found in respiratory symptoms and pulmonary functions between welders and controls are not overestimated.

We conclude that welders have an increased risk of chronic bronchitis and impairment of pulmonary function. It seems that a strong effort should be made to persuade welders to stop smoking; better ventilation should be attained, and welders should wear respiratory protective devices.

1 Sferlazza SJ, Beckett WS. The respiratory health of welders. Am Rev Respir Dis 1991;143:1134-48.

2 Stern RM, Berlin A, Fletcher A, Hemminki K, Jarvisalo J, Peto J. International conference on health hazards and biological effects of welding fumes and gases. Int Arch Occup Environ Health 1986;57:237-46.

3 Morgan WKC. On welding, wheezing and whimsy. Am Ind Hyg Assoc F 1989;50:59-69.

4 Groth M, Lyngenbo O. Respiratory symptoms in Danish welders. Scand $\mathcal{F}$ Soc Med 1989;17:271-6.

5 Fogh A, Frost J, Georg J. Respiratory symptoms and pulmonary function in welders. Ann Occup Hyg 1969;12: 213-8.

6 Kleinfeld M, Messite J, Kooyman O, Shapiro J. Welders' siderozis. Arch Environ Health 1969;19:70-3.

7 Oxhoj H, Bake B, Wedel H, Wilhelmsen L. Effects of electric arc welding on ventilatory lung function. Arch Environ Health 1979;24:211-7.

8 Peters JM, Murphy RLH, Ferris BG, Burgess WA, Ranadive MV, Perdergrass HP. Pulmonary function in shipyard welders. Arch Environ Health 1973;26:28-31.

9 Rastogi SK, Gupta BN, Husain T, Mathur N, Srivastava S. Spirometric abnormalities among welders. Environ Res 1991;56:15-24.

10 Medical Research Council. Questionnaire of respiratory symptoms. London: MRC, 1976.

11 American Thoracic Society. Standardization of spirometry. Am Rev Respir Dis 1979;119:831-8.

12 Kilburn KH, Warshaw RH. Pulmonary functional impairment from years of arc welding. Am ₹ Med 1989;87:62-9.

13 Lyngenbo O, Groth S, Olsen O, Rossing N. Occupational lung function impairment in never-smoking Danish welders. Scand $\mathcal{F}$ Soc Med 1989;17:157-64.

14 Cotes JE, Feinmann EL, Male VJ, Rennie FS, Wickham CAC. Respiratory symptoms and impairment in shipyard welders and caulker/burners. $\mathrm{Br} F$ Ind Med 1989 46:292-301.

15 Hunnicut TN, Cracovaner $\mathrm{Dj}$, Myles JT. Spirometric measurements in welders. Arch Environ Health 1964;8:661-9.

16 Sjögren B, Ulfvarson U, Tech D. Respiratory symptoms and pulmonary function among welders working with aluminium, stainless steel and railroad tracks. Scand $f$ aluminium, stainless steel and railro

17 McMillan GH, Heath Y. The health of welders in naval dockyard: acute changes in respiratory function during standardized welding. Ann Occup Med 1979;31:43-60.

18 Hayden SP, Pincock AC, Hayden J, Tyler LE, Cross KW, Bishop JM. Respiratory symptoms and pulmonary function of welders in the engineering industry. Thorax 1984;39:442-7.

19 Becklake MR. Chronic airflow limitation: its relationship to work in dusty occupations. Chest 1985;88:608-17.

20 Dosman JA, Kania J, Cockroft DW. Occupational obstructive disorders. Med Clin North Am 1990;74:823-35.

21 Garshick E, Schenker MB Occupation and chronic airflow Garshick E, Schenker MB. Occupation and chronic airfow 43:227-58. 